\title{
MENINGKATKAN KEMAMPUAN FISIK MOTORIK HALUS MELALUI KEGIATAN MENGANYAM DENGAN BENTUK BAHAN ALAM PADA ANAK KELOMPOK A DI TK PEMBINAAMEN KECAMATAN AMEN KABUPATEN LEBONG
}

\author{
(Improving Fine Motor Physical Abilities \\ Through Weaving Activities With The Form of Natural Materials in Group a Children in TK \\ Pembina Amen Lebong Regency) \\ Amanah Rahma Ningtyas,M.Pd \\ PIAUD IAIN Curup \\ Jalan AK Gani No. 01 Bengkulu 39119 \\ Email: amanahrahma@iaincurup.ac.id*
}

\begin{abstract}
Abstrak
Perkembangan motorik adalah perkembangan pengendalian gerak jasmani melalui kegiatan pusat syaraf, urat syaraf dan otot terkoordinasi. Perkembangan motorik halus seperti menggenggam,merangkak, duduk dan berjalan akan mendasari perkembangan lainnya yang lebih kompleks. Perkembangan fisik motorik anak dapat ditingkatkan melalui kegiatan menganyam dengan bahan alam seperti memberikan kebebasan pada anak untuk bereksplorasi dan beraktifitas sesuai perkembangan anak. Tujuan dan perbaikan kegiatan pengembangan kemampuan pada penelitian ini adalah untuk meningkatkan kemampuan motorik halus anak melalui kegiatan menganyam dengan bahan alam pada anak kelompok A di TK Pembina Amen Kecamatan Amen Kabupaten Lebong. Subyek penelitian ini adalah anak-anak,pendidik, Kepala Sekolah serta metode pembelajaran. Penelitian ini dilaksanakan pada semester 1tahun ajaran 2019/2020 di TK Pembina Amen Kecamatan Amen Kabupaten Lebong. Adapun cara penelitiannya adalah menggunakan pelaksanaan perbaikan dua siklus. Pada siklus I dibuat kegiatan yang seharusnya mampu dicapai anak. Pada siklus I Persentase ketercapaian anak masih dibawah $85 \%$. Maka,diadakan perbaikan pada siklus II dan terdapat Siklus peningkatan persentase sebesar 93,3\%. Peningkatan kemampuan fisik motorik halus anak disebabkan karena guru menggunakan metode dan media pembelajaran yang sesuai karakteristik anak. Berdasarkan hasil penelitian diperoleh kesimpulan bahwa kegiatan menganyam dengan bahan alam dapat meningkatkan kemampuan fisik motorik halus anak. Hal ini terlihat dari hasil ketercapain ketuntasan belajar anak yang mengalami peningkatan dalam siklus di setiap pertemuan.
\end{abstract}

Abstract

The motor development is physical movement controller with nervous center activity, nerves, cordinated muscle. fine motor development as holding,crawl, sit, and walk will underlying development and the other more complex. Physical motor development of children can be improved through weaving activities with natural materials such as giving children the freedom to explore and do activities according to the child's development. The purpose and improvement of ability development activities in this study was to improve children's fine motor skills through weaving activities with natural materials in group A children in TK Pembina Amen, Amen, Lebong. The subjects of this study were children, educators, school principals and learning methods. This research was carried out in semester 1 of the 2019/2020 academic year at TK Pembina Amen, Amen, Lebong. The research method is to use the implementation of two cycles of improvement. In the first cycle, activities are made that should be able to be achieved by children. In cycle I the percentage of children's achievement is still below $85 \%$. So, improvements were made in cycle II and there was a cycle of increasing the percentage of $93.3 \%$. The increase in children's fine motor physical abilities is caused by the teacher using learning methods and media that are suitable for the child's characteristics. Based on the results of the study, it was concluded that weaving activities with natural materials can improve children's fine motor physical abilities. This can be seen from the results of children's learning mastery which has increased in cycles at each meeting. 


\section{PENDAHULUAN}

Menurut Undang Undang

Sisdiknas Tahun 2003 No 20 pasal 1 ayat Pendidikan Anak Usia Dini adalah upaya pembinaan yang ditujukan kepada anak sejak lahir sampai dengan usia 6 tahun, yang dilakukan melalui pemberian rangsangan pendidikan untuk membantu pertumbuhan dan perkembangan jasmani dan rohani, agar anak memiliki kesiapan dalam memasuki pendidikan lebih lanjut.

Pendidikan Anak Usia Dini dalam Undang-Undang Republik Indonesia Nomor 20 Tahun 2003 tentang Sistem Pendidikan Nasional Pasal 28 ayat 3 menyatakan bahwa Pendidikan Anak Usia Dini pada jalur pendidikan yang bertujuan membantu anak didik mengembangkan berbagai potensi baik psikis maupun fisik yang meliputi moral dan nilai agama, sosial emosional, kemandirian, kognitif, bahasa, fisikmotorik, dan seni untuk siap memasuki sekolah dasar. Inilah mengapa pada masa anak-anak disebut masa keemasan. Pada masa inilah adanya kepekaan dan kepedulian dari generasi dewasa untuk memfasilitasi potensi, bakat dan minat kreatifitas mereka. Hal ini sesuai yang tercantum dalam UndangUndang Nomor 23 tahun 2002 tentang Perlindungan anak pasal 9 yang mengemukakan semua anak mendapatkan hak pendidikan dan pengajaran untuk mengembangkan pribadinya dalam meningkatkan bakat dan minat anak. Anak diberikan kesempatan untuk mengasah dan mengembangkan kreatifitasnya, agar anak dapat meraih impiannya dan mewujudkan seluruh generasi bangsa yang bermartabat dan memiliki kepedulian dan empati terhadap sesama.

Perkembangan motoric erat kaitannya dengan perkembangan pusat motorik di otak. Ketrampilan motorik berkembang sejalan dengan kematangan syaraf dan otak. Oleh Sebab itu setiap gerakan yang dilakukan anak sesederhana apapun sebenarnya merupakan hasil pola interaksi yang kompleks dan berbagai bagian dan sstem dalam tubuh yang di kontrol otak.

Pertumbuhan tercepat anak-anak terjadi sepanjang tiga tahun pertama, terutama selama beberapa bulan pertama. Pada bulan kelima, berat rata- rata bayi laki- laki telah berlipat dua: mencapai 16 pound, dan pada usia satu tahun, berat tersebut hampir berlipat tiga menjadi 23 pound. Pertumbuhan yang pesat tersebut kemudian mereka pada tahun kedua ketiga dari usianya anak laki- laki biasanya naik sekitar 5 pon pada ulang tahun keduanya dan $31 / 2$ pon pada ulang tahun ketiganya (Papalia,2008).

Perkembangan fisiologis berkaitan dengan perubahan yang terjadi pada tubuh manusia, seperti menjadi tinggi atau menjadi lebih besar. Perkembangan fisiologis sejalan dengan perkembangan otak dan susunan saraf pusat, perkembangan tubuh, perkembangan otot kasar, otot halus dan koordinasi gerakan motorik kasar dan motorik halus serta koordinasi gerakan visual motorik. Perkembangan motorik kasar berkaitan dengan perkembangan kemampuan dalam menggerakkan tubuh baik secara sebagian (non lokomotorik) yaitu perkembangan kemampuan menggerakkan sebagian dari tubuh, seperti menjangkau untuk mengambil sesuatu dan kemampuan dalam menggerakkan tubuh secara keseluruhan (lokomotorik) yang terjadi pada waktu berjalan, berlari, melompat, olah raga, dll, dan gerakan pada waktu menarik dan mendorong. Pada usia dini kegiatan motorik anak sangat aktif dan mereka bergerak seolah- olah tidak pernah lelah (Santrock, 1995).

Perkembangan motorik halus berkaitan dengan perkembangan kemampuan dalam menggunakan jari- jari tangan untuk melakukan berbagai kegiatan, seperti gerakan dalam menjimpit, menggenggam, menulis, memotong, menggunting, dll. Pada usia 4 tahun koordinasi gerakan motorik halus anak sudah hampir sempurna. Walaupun demikian, anak masih mengalami kesulitan 
dalam menggunakan jari- jari tangannya untuk menyusun balok-balok kecil menjadi bangunan. Hal ini bukan disebabkan karena ia tidak dapat menggunakan jari-jari tangannya dalam menyusun balok, akan tetapi, disebabkan oleh keinginannya untuk meletakkan balok- balok secara sempurna, sehingga kadang- kadang meruntuhkan bangunan yang telah ia buat dari susunan balokbalok kecil tersebut. Santrok (1997) menjelaskan Pada usia 6 tahun perkembangan koordinasi gerakan motorik halus anak berkembang dengan pesat, seperti mengkoordinasikan gerakan mata dengan gerakan tangan pada waktu menulis, menggunting, menempel, melipat atau menganyam, dll.

Dalam aspek perkembangan fisik motorik halus terkait dengan kecerdasan kinestetik pada anak usia dini. Amstrong dalam Musfiroh menjelaskan bahwa kecerdasan kinestetik adalah kemampuan menggunakan seluruh tubuh (fisik) untuk mengekspresikan ide dan perasaan (dalam bentuk berpantomim, menari, berolahraga) dan ketrampilan menggunakan tangan untuk menciptakan atau mengubah sesuatu (membuat kerajinan, membuat patung, menjahit. Amtrong juga mengungkapkan bahwa kecerdasan kinestetik berarti belajar serta berpikir dengan tubuh. Kecerdasan ditunjukkan dengan ketangkasan tubuh dalam memahami perintah otak. Ini terlihat bahwa ada keterkaitan antara aspek perkembangan fisik motorik dengan kecerdasan kinestetik. Aspek perkembangan fisik motorik halus yang mendapatkan stimulus yang sesuai makan kecerdasan kinestetik akan berkembang maksimal.

Kemampuan motorik halus anakanak di TK Pembina Amen menunjukkan keterlambatan khususnya dalam kegiatan menganyam. Sebagai upaya dalam meningkatkan kreatifitas anak maka perlu diiringi peningkatan kemampuan motoric halus anak. Hasnawati (2017) menjelaskan bahwa menganyam dalam arti pendidikan berarti mengatur bilah atau lembaran lembaran yang diatur tersebut berupa bambu, daun, janur, kertas, rotan, kulit binatang atau kain perca. merupakan salah satu hasil kerajinan masyarakat Indonesia. Menganyam merupakan kegiatan yang bisa membuat dan menghasilkan benda menjadi alat kerajinan/ seni yang dilakukan dengan menumpang tindihkan bagian-bagian yang digunakan untuk menganyam secara bergantian.

Kegiatan menganyam bisa dilakukan dengan berbagai macam benda. Asmawati mengatakan bahwa banyak jenis yang bisa digunakan dalam berhitung, membuat berbagai bentuk hewan, membuat sumber bunyi-bunyian, untuk mengecap suatu gambar dengan menggunakan batu kerikil, jenis daundaunan, pelepah pisang, dan jenis tumbuhan lainnya(Asmawati,2014). Pada anak usia dini menganyam bisa dilakukan dengan menyesuikan bahan dengan tahapan perkembangan anak. Anak bisa diajak melakukan menganyam dengan kertas berwarna. Kegiatannya bisa beraneka ragam membuat tas, membuat lampion dan kerajinan yang lain.

Kegiatan menganyam dengan menggunakan bahan dan alat yang bersumber dari lingkungan dan yang ada di sekitar anak. Misalnya dengan menggunakan kertas, daun pisang, janur, daun pandan, bambu, dan sebagainya. Proses kegiatan menganyam disesuaikan dengan usia anak. Pada anak usia 4-6 tahun jumlah benda untuk di anyam bisa lebih dari 1, dan jumlah tumpang tindihkan bagian-bagian yang dianyam juga disesuikan dengan perkembangan anak. Bahan alam banyak sekali manfaatnya pada pembelajaran anak usia dini. Lingkungan alam sekitar merupakan lingkungan yang dekat dengan anak dan mampu membuat anak tertarik dalam kegiatan pembelajaran dengan bahan alam. Sujana dan Rivai (2010) mengatakan bahwa pembelajaran yang membuat anak tertarik serta dapat masuk dalam pemikiran anak dalam ingatan jangka panjang adalah pembelajaran yang 
diciptakan dengan hal yang nyata yang dilakukan langsung oleh anak, dalam implementasinya alat dan bahan yang digunakan harus yang dekat dengan lingkungan sekitar anak, agar anak dapat memahami dengan baik serta terlibat aktif dalam hal tersebut.

Menurut Torquati (2016) Bahanbahan di sekitar anak selain mudah di dapatkan juga mudah diimplementasikan pada anak usia dini. Dalam sebuah penelitian menyatakan bahwa kegiatan saintifik sangat membantu anak dalam memahami apa yang terjadi di sekitarnya. Tahapan proses saintifik tersebut adalah proses mengamati, menyebutkan, menjelaskan, membedakan, menganalisis, membuat kesimpulan dan melaporkan penemuan. Implementasi dengan kegiatan yang melibatkan lingkungan sekitar anak sangat sesuai dalam pembelajaran anak.

\section{METODE PENELITIAN}

Pada penelitian ini menggunakan jenis penelitian dengan tindakan kelas yang dilakukan di PAUD. Penelitian ini dilakukan pada semester genap tahun pelajaran 2020/2021. Subjek penelitian ini adalah anak kelompok A di PAUD . Teknik pengumpulan data menggunakan observasi dan wawancara. teknik data yang digunakan dalam penelitian ini yaitu analisis kualitatif. Analisis kualitatif dilakukan terhadap data kualitatif yang diperoleh dari hasil pengamatan terhadap siswa dan hal-hal lain yang nampak selama berlangsungnya penelitian.

Demikian juga aktivitas dan antusias siswa dalam pembelajaran juga didasarkan pada banyaknya indikator yang muncul. Selanjutnya dari hasil catatan dalam penelitian dilengkapi dengan hasil observasi, wawancara dan dokumentasi dilakukan analisis kualitatif. Teknik analisis data yang digunakan untuk mengolah data yang dihasilkan dari penilaian perkembangan anak dengan metode pemberian tugas. Teknik analisis data yang digunakan dalam penelitian ini adalah model analisis interaktif, yang meliputi pengumpulan data, reduksi data, penyajian data, dan penarikan kesimpulan (Sugiyono,2014:338).

\section{HASIL DAN PEMBAHASAN}

Sesuai dengan kegiatan pelaksanaan yang telah dilakukan selama 2 bulan dengan masing-masing siklus sebanyak 5 pertemuan, diperolah bahwa adanya peningkatan kemampuan fisik motorik halus anak. Peningkatan kemampuan fisik motrik anak melalui kegiatan meganyam dengan bahan alam.

Siklus I Pada pertemuan pertama anak-anak belum mampu mengenal tata cara menganyam dengan benar, sehingga penilaian anak dalam menganyam dengan bahan alam mencapai $65 \%$ dan dikatakan belum mencapai standar minimal yaitu $85 \%$

Pada pertemuan kedua guru mengenalkan cara menganyam dengan bahan alam supaya kegiatan motorik halus bisa dianalisis dari RPPH II anak yang mampu melaksanakan tugasnya baru mencapai $68,3 \%$.

Pertemuan Ketiga guru melakukan kegiatan menganyam dan persentase hasil keseluruhan mencapai 73,9\%

Pertemuan keempat guru mengajak anak menganyam dengan pola mudah T1, A1, T1, A1,... Hasil yang dicapai $79 \%$.

Pertemuan kelima kegiatan menganyam bisa dikatakan mulai lancar karena anak-anak sudah bisa memahami tentang belajar menganyam tersebut, pada $\mathrm{RPPH}$ ini hasil yang dicapai keseluruhan $80,6 \%$.

Siklus II Pada pertemuan pertama, kegiatan menganyam anak-anak belum terlihat antusias dan berminat untuk melakukan kegiatan, dan sebagian masih terlihat pasif dan diam, sehingga pendidik berusaha untuk menarik minat anak. Sebagian masih belum mampu, dan masih belum paham dengan penjelasan yang telah disampaikan oleh pendidik. Berdasarkan hasil analisis data penilaian anak dalam menganyam hanya mencapai $84,9 \%$ dan dikategorikan belum mencapai 
ketuntasan menurut standar ketuntasan minimal yang telah ditetapkan yaitu $85 \%$.

Pada pertemuan kedua, anak-anak melakukan kegiatan menganyam dari daun janur pola T1, A2, T1, A2,.., anak-anak masih kurang maksimal, anak-anak masih diam dan pendidik harus selalu menuntun dengan memberi contoh menyuruh anak anak menirukannya. Berdasarkan hasil analisis dari RPPH 2 ini hanya bisa mencapai $87,2 \%$, dan sudah di kategorikan mencapai standar ketuntasan minimal.

Pada pertemuan ketiga, kegiatan membuat anak dalam kegiatan pertemuan ketiga, keseluruhan adalah $88,9 \%$, menganyam dari daun janur anak-anak terlihat ada peningkatan dalam minat. Hasil persentase $91,7 \%$ dan dikategorikan sudah mencapai ketuntasan yang telah ditetapkan yaitu $85 \%$ standar ketuntasan minimal.

Pada pertemuan keempat, pendidik mengajak anak-anak melakukan kegiatan menganyam dari daun janur anak - anak terlihat berusaha untuk menganyam walau masih dengan menirukan contoh pendidik. Hasil yang dicapai secara keseluruhan adalah $91,7 \%$ dikategorikan sudah mencapai Standar Ketuntasan Minimal.

Pada pertemuan kelima, kegiatan menganyam dari iratan bambu yang di beri warna terlihat ada peningkatan dari pertemuan sebelumnya, anak-anak terlihat tertarik dengan menganyam, metode anak juga terlihat ada peningkatan dalam kemampuan . Pada RPPH 5 ini hasil yang dicapai untuk berdasarkan minat 95\%, berdasarkan kemampuan menganyam 93,3\% dan untuk kerapian 91,7\% secara keseluruhan adalah $93.3 \%$. Dikategorikan hasil ini telah memenuhi tingkat keberhasilan yaitu $85 \%$.

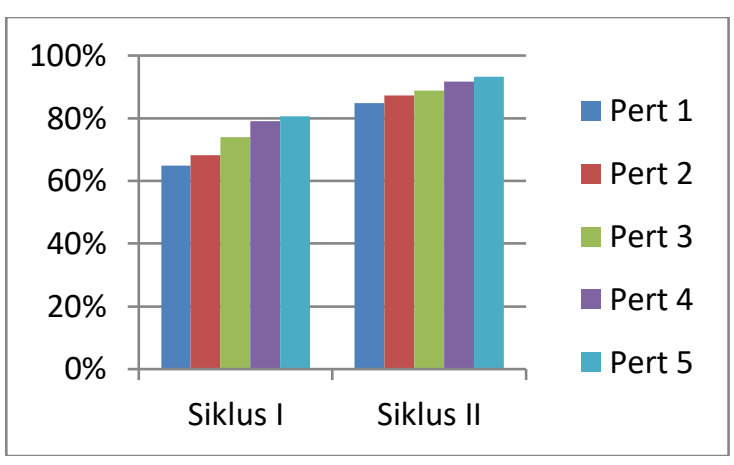

Gambar 1. Grafik Tabel Hasil Kegiatan Menganyam dengan bahan alam terhadap Peningkatan Kemampuan Fisik Motorik Halus

Berdasarkan uraian yang telah dikemukakan di atas dapat dinyatakan bahwa kegiatan menganyam dengan bahan alam dapat meningkatkan terhadap kemampuan fisik motorik halus anak. Hal ini dikarenakan bermain menganyam dengan memanfaatkan bahan alam anak akan tertarik dan membuat aspek motorik halus meningkatkan karena menggunakan semua jari jemarinya untuk menggerakkan satu persatu dalam kegiatan menganyam

\section{KESIMPULAN}

Menganyam dengan bahan alam dapat melatih konsentrasi anak sehingga koordinasi antar tangan dan mata bisa baik. Mempermudah pembelajaran motorik halus lainnya. Contoh : menggunting, mencocok, mewarnai. Pembelajaran motorik halus bisa merangsang kelenturan jari jemari anak. Dari siklus 1 dan 2 dapat diambil kesimpulan bahwa siklus 1 dari RPPH 1 sampai 5 belum persentase masih dibawah $85 \%$. Pada siklus 2 setelah diadakan perbaikan persentase meningkat jadi $93,3 \%$.

Dengan demikian pembelajaran peningkatan motorik halus melalui kegiatan menganyam dengan bahan alam bisa dikatakan berhasil. Pembelajaran dengan bahan alam membuat proses kegiatan belajar anak menarik dan menyenangkan. Dengan pembelajaran yang menyenangkan akan membuat 
pengalaman yang bermakna bagi anak usia dini. Jadi pembelajaran di TK harus mengutamakan tingkat perkembangan anak supaya pembelajaran berhasil degan baik dengan menggunakan metode dan media pembelajaran yang sesuai dengan karakteristik anak.

DAFTAR PUSTAKA

Papalia, Diane E, Etc. 2008. Human Development (Psikologi Perkembangan, terjemahan A. K. Anwar). Jakarta: Kencana Prenada Media Grup

Hasnawati,. Brantasari, 2017. Meningkatkan Konsentrasi Anak dengan Kegiatan Menganyam Kain Perca pada Anak Usia 5-6 tahun di TK Tunas Muda Kersik Kec. Marangkayu Kab. Kutai Kartanegara. Jurnal Warna : Jurnal Pendidikan Dan Pembelajaran Anak Usia dini. 2 (2). Hal. 38-52

Santrock W John. 1995. Life Span Development, Jakarta: PT Erlangga, 1995.

Torquati, J. (2010). Environmental Education. A Natural Way to Nuture Children's Development and Learning. Proquest Educational Journal, 65 (6), 98. Diperoleh pada 2 Februari 2016 melalui http://eric.ed.gov/

Asmawati, L. 2014. Perencanaan Pembelajaran di Taman KanakKanak. Bandung: PT. Remaja Rosdakarya Offset.

Sudjana, N.\& Rivai, A. 2010. Media Pengajaran. Bandung: Sinar Baru Algesindo.

Sugiyono. 2014. Metode Penelitian Pendidikan: Pendekatan Kuantitatif, Kualitatif, dan R\&D. Bandung: Alfabeta 